\title{
The effects of occupational stress on burnout and life satisfaction: a study in accountants
}

\author{
Azzem Ozkan · Mahmut Ozdevecioğlu
}

Published online: 26 February 2012

(C) The Author(s) 2012. This article is published with open access at Springerlink.com

\begin{abstract}
The aim of this study is to determine the impact of occupational stress on burnout and life satisfaction in accountants. The study deals with burnout from three dimensions: emotional exhaustion, lack of personal accomplishment and depersonalization. Certain hypotheses were developed according to a model. These hypotheses mainly measure the negative impact of occupational stress on life satisfaction and its positive impact on burnout. In order to test these hypotheses, a study was conducted in 217 accountants in the city of Kayseri in Turkey. On the research revealed that occupational stress has a negative impact on life satisfaction, while it has a positive impact on the three dimensions of burnout listed above. Based on these results, the study argues that occupational stress is an important factor in determining the life satisfaction and burnout levels of accountants. Finally in this study, some limitations and recommendations are presented for the researchers of future studies.
\end{abstract}

Keywords Occupational stress - Life satisfaction - Burnout - Emotional exhaustion · Depersonalization · Lack of Personal accomplishment

\section{Introduction}

On the one hand, the business world experiences a great deal of rapid change and transformation, and on the other hand it feels the side-effects of these changes in terms of labour conditions and standards. Therefore, workers are affected both by the stress of the business world and by occupational stress. The stress borne by individuals is very important in terms of the period in which the stress is faced and how great the stress is. In this study, the high levels of stress experienced by accountants are the main subject of research. The main aim of the study is to define the effects of occupational stress on life satisfaction and burnout in accountants. Life satisfaction is also substantial in terms of understanding the behavior and manners of individuals. Performance, well-being, future expectations and happiness are

\footnotetext{
A. Ozkan $(\varangle) \cdot$ M. Ozdevecioğlu

Department of Business Administration, School of Economics and Business Administration,

Erciyes University, Kayseri, Turkey

e-mail: azzem@erciyes.edu.tr
} 
directly related to the life satisfaction of workers. Burnout is a serious problem which is experienced from time to time in some professions. The difficulties of the profession or work results in individuals experiencing burnout. In this respect, our study handles the effects of occupational stress from two important perspectives; life satisfaction and burnout. The limited number of studies conducted on burnout in professionals working in the field of accountancy makes this study even more important for both theoricians and executives.

The primary reason for choosing accountants is that these individuals work under considerable stress. Factors such as the need for punctuality, intolerance for mistakes, heavy workload, continuous changes in the regulations in force and the need for high level of concentration are working conditions which increase the level of stress in this profession.

\subsection{Stress and occupational stress}

One of the most frequently faced psychological problems of recent years is stress and stress related illnesses. Due to an ever changing world, everybody is affected by stress regardless of age, gender, profession, social or economic status. Because of these rapid changes, people live most of their lives under stress. Therefore, the notion of stress has become a widely recognized problem in all aspects of life. Deriving from the Latin word "estricia" and "esterece" in French, stress is the English word. In lexicological terms, stress meant difficulty, problem or bad luck in the 14th century, disaster, trouble, sorrow in the 17th century and force, pressure and obligation in the 18th and 19th centuries it later come to mean enforcements against humans, organs or psychological structure (Baltas and Baltas 1990).

The first definition of the notion of stress goes back to ancient China. However, there have been many considerable changes in the meaning of the word "stress". (Gokdeniz 2005). During the course, changes in conditions of life, threats and opportunities, caused change in the definition of stress and stress related sources. The first definition related to stress was given by Cannon in (1914). For Cannon, stress is the physiological stimulus necessary for retrieving the inner balance disturbed by unwanted environmental effects (Erdogan 1996). In today's world, the concept of stress was first used by Hans Selye. For Selye (1977) stress is "an unspecial reaction that the body shows for any outer effect". Ivancewich et al. (1983) defined stress as "all the results of an interaction between the individual and the destructive event". Magnuson simply described stress as the reaction of the individual to the difference between his/her expectations and the real world (Magnuson 1990). In other words, stress is explained as the result of a reaction against an action, an event or physical and/or psychological pressure (Hellriegel et al. 1983). Moreover, Eren (2006) defined stress as "intellectual and physical reaction of human body through special secretions due to the effects of their environment and working conditions". In other studies, we can find even more expansive explanations. However, according to the widely accepted definition in the academicals environment, stress "is the result which is reflected to the organism after an adaptive behavior as a reaction in the course of individual differences and psychological processes; any environmental event causing psychological and/or physiological pressure"(Artan 1986).

When definitions of stress are evaluated, primarily the individual effects of stress are emphasized, it was found that the relationship between work life and stress is generally ignored. However, in time, researchers realized that stress, causing sorrow, depression, failure and distress individually, is a very vital factor in working life and a subject of research in organizational structure.

Those individuals accomplishing specific roles and duties in the work environment also face stress in the organizational environment. In every step of daily life stress can be termed "occupational stress", "organizational stress" or "work stress". Occupational stress can be 
defined as the adaptive reaction to external conditions that cause physical, psychological and behavioural irregularities (Aktas and Aktas 1992). Just as Erdogan (1996) defined occupational stress as "a circumstance that emerges from the relationships between individuals and their works and that keeps the individual away from humane functions. Moreover, Beehr and Newman (1978) described occupational stress as a state determined by changes forcing humans to differentiate from their normal functions and it emerges from their dealings and relationships with other people.

Stress that affects the workers in an organization may be due to heavy workload, shortage of time, lack of or excessive control, imbalanced responsibilities or authorization, incompatibility between the values of individuals and the organization, uncertainty of roles, discord between the individual and the profession, conflict of roles, anxiety about responsibilities, working conditions, fear of losing job, dangers of the job and relationships between individuals (Davis and Newstrom 1988). Stress, which originates from these kinds of reasons, on the one hand causes negative physical, psychological and behavioural outcomes in the individual, and on the other hand it causes lack of performance, latecoming, absency, increase in workpower transfer and accidents at work (Yilmaz and Ekici 2003; Mackay et al. 2004; Ugoji and Isele 2009; Stacciarini and Troccoli 2004; Mansor et al. 2003; Fairbrother and Warn 2003; Antoniou et al. 2003)

Reasons for occupational stress are classified differently by researchers. There have been more than 250 studies on the reasons for occupational stress in the last 25 years (Aydin 2004). Kahn and Byosiere (1995), after analysing the results of such studies, stated that it is proper to classify the sources of occupational stress into two categories; content of the work and role.

Cooper and Marshall (1976) stated in their study on occupational sources of stress that there are five major sources of stress, which cause occupational stress overload. These are:

- Items inherent in the profession

- Roles in the organization

- Career development

- In-job relationships

- Organizational structure and climate

On the other hand, individuals in some professional fields face more occupational stress than others. This is because some occupations involve emotional elements and therefore individuals in these professions face much more stress than those in professions not required to express emotions (Saldamli 2008). In addition, the necessity to perform the job without making mistakes, the need to keep work under continuous control, the obligation to obey all the various laws, having to work away from other people and the necessity for high concentration levels keep some occupations high up in the list of stress levels.

Occupational stress threatens countries that are rapidly developing and involved in the process of industrialization due to its being a factor which may cause mistakes and accidents in the work place (Haratani and Kawakami 1999: www.cdc.gov/niosh/stress99.html). On the other hand, individuals who work in international companies and are continuously in contact with these companies as a result of globalization, home offices that force individuals to work 24 hours a day with the help of satellite, internet or wireless networks and intercultural conflicts have emerged as new sources of occupational stress (Mansor et al. 2003).

Accountants are one of those professional groups which face increased stress in today's work environment. Because accountancy depends mainly on intellectual activities, needs continuous attention and causes great loss of energy, it is a tiring and exhausting profession (Ertas 2002). Today, there are many duties that accountants have to perform which require a great 
deal of attention. Examples include accountancy of VAT, montly tax declarations, paying taxes, arrangement of monthly insurance premiums, declaration and payment of insurance, issuing forms and declarations about the purchases and sales of customers over a specific amount, confirmations with second parties, records of receipts and documents, accounts and declaration of three-month temporary taxes, arranging annual reports, accounts and declaration of institutional taxes after profits, solving conflicts with government offices (Tax Office, Department of Social Security, Chamber of Commerce...), company establishments, transfers, unions, the liquidation of companies and such like. Naturally, all these activities have to be performed with great concentration, attention and care. Otherwise, accountants may incur considerable fines together with his/her clients. Obviously, workload, extra levels of care and the threat of legal fines increase levels of stress and therefore cause burnout together with a lack of life satisfaction.

Some studies have been conducted on measuring the occupational stress levels of certain professions. However, there are only a limited number of studies measuring the stress level of accountants. Yildirim (2008) reported in a recent study that the stress levels of female workers is much higher than that of male workers that stress level does not differ with the position of workers that there is almost no difference between the stress levels of accountants and professors of accountancy, and that individuals between the ages of 20 and 29 face more stress than others.

\subsection{Burnout}

Stress which is accepted as a natural part of business life, may actually be "burnout". (Cokluk 2000). Freudenberger (1974) defined burnout as "use up of inner sources of individuals due to exhaustion, loss of energy or demands not met".

Today, the most widely accepted definition of burnout is that given by Maslach and Zimbardo (1982). They (1982) approached the notion of burnout in three dimensions: emotional exhaustion, depersonalization and lack of personal accomplishment. According to this view, burnout is divided into three categories, as emotional exhaustion, depersonalization and lack of personal accomplishment, that are widely observed in individuals who work in close relation to other people while performing their jobs (Maslach and Zimbardo 1982). Emotional exhaustion implies individual stress and means an increase in the emotional and physical demands made on the individual. Depersonalization represents the interpersonal dimension of burnout together with negative manners towards clients and a lack of interest in work. In addition, a feeling of lack of personal accomplishment shows the tendency of negative evaluation in an individual (Maslach et al. 2001; Wright and Bonnet 1997; Budak G, Surgevil 2005).

It is clear that burnout is related to the personal, family and organizational life of the individual. It has been widely shown in the literature that individuals who feel burnout display tiredness, psychosomatic problems, failures in psychological health and a tendency to distance themselves from family members (Surgevil 2006; Ardic and Polatsci 2008). Likewise, it has been pointed out that burnout may cause decreased performance an increase in the personal turnover pace, absences and negative effects on productivity (Schaufeli and Buunk 2003; Maslach and Leiter 1997; Kop and Euwema 2001).

Another study on determining the burnout level of accountants was conducted by Ay and Avsaroglu (2010). In their study, they reported that the emotional exhaustion level was meaningfully differentiated in terms of gender but with only average levels for depersonalization and far lack of personal accomplishment there was no difference. They found that there was an increase in depersonalization and personal accomplishment according to length of service 
while no change was seen for emotional exhaustion. As regards gender, there was difference in emotional exhaustion whereas no difference was observed in depersonalization and personal accomplishment levels. The regional effect, work styles and type of work place were also considered and it was stated that in depersonalization, emotional exhaustion and lack of personal accomplishment levels, there are meaningful changes.

\subsection{Life satisfaction}

Life includes all the time that an individual spends in and out of work (Dikmen 1995). However, life satisfaction is the general attitude of an individual towards life itself (Ozdevecioğlu 2003). As life is complex and covers a wide range of factors, creating definitions about life satisfaction or describing the factors involved in life satisfaction is quite difficult. Moreover, there is ambiguity in defining the concept and what it entails depending on the level of perception of each individual. Therefore, one can find many different definitions and approaches. Below, we present some of these definitions:

- Life satisfaction, in general, represents personal satisfaction about his/her own life (Telman and Ünsal 2004).

- Life satisfaction shows the result of comparison of personal expectations and reality. When we use the term "life satisfaction", we understand a general satisfaction, not about a specific event (Ozdevecioğlu and Aktas 2007).

- Life satisfaction is a summary of evaluation on the parts that the individual likes or dislikes in his/her own life. (Heller et al. 2002).

Frequently, the notion of life satisfaction is used as a synomym of some other notions or it is misused. One of these notions is happiness and the other is subjective well-being (Saris et al. 1996). Some scientists have used these notions as having the same meaning while others stated that they are different. However, when the meanings of these notions are considered in detail, one has to admit that their meanings are really quite different. For example, life satisfaction states a momentary feeling while happiness may be because of future expectations. The individual may have a bad life. Therefore, his/her level of life satisfaction is low. However, he/she may feel happy about these because days are signs of good days to come (Dikmen 1995). The notion of subjective well-being depends more on physical and psychological determiners, that is, how good an individual feels physically and mentally independent of wealth, marital status or occupation (Bastemur 2006).

Veenhoven (1991) conducted 245 studies in 32 countries and according to the results of these studies the factors involved in life satisfaction can be stated as follows (Dockery 2004):

- Living in an economically wealthy country where freedom and democracy are accepted.

- Political stability.

- Being a part of the majority rather than the minority.

- Being in the upper part of the social structure.

- Being married and having good realtionships with his/her family and friends.

- Being physically and mentally healthy

- Being openminded and active

- Having the feeling that he/she controls his/her own life.

- Instead of merely earning money and being politically conservative, being willing to adherent to social and ethical values.

When we consider accountancy in terms of life satisfaction, being an accountant is tiring, depends on mental activity, needs continuous attention and care, causes loss of energy 
and therefore exhaustion; all these factors results in stress. There have been alternative hypotheses that this stress causes burnout and an increase in the level of life satisfaction of accountants. However, we have not as yet found any study on the life satisfaction of accountants in the literature.

We conducted our study on accountants in Kayseri, a city in central Turkey, to determine the effects of occupational stress levels on burnout and life satisfaction of accountants. The model, hypotheses and findings are presented below.

\section{Research model}

\subsection{Research model and hypotheses}

Within the context of this study, we created a theoretical model in order to examine the effects of occupational stress on life satisfaction, emotional exhaustion, lack of personal accomplishment and depersonalization. Our model is outlined below:

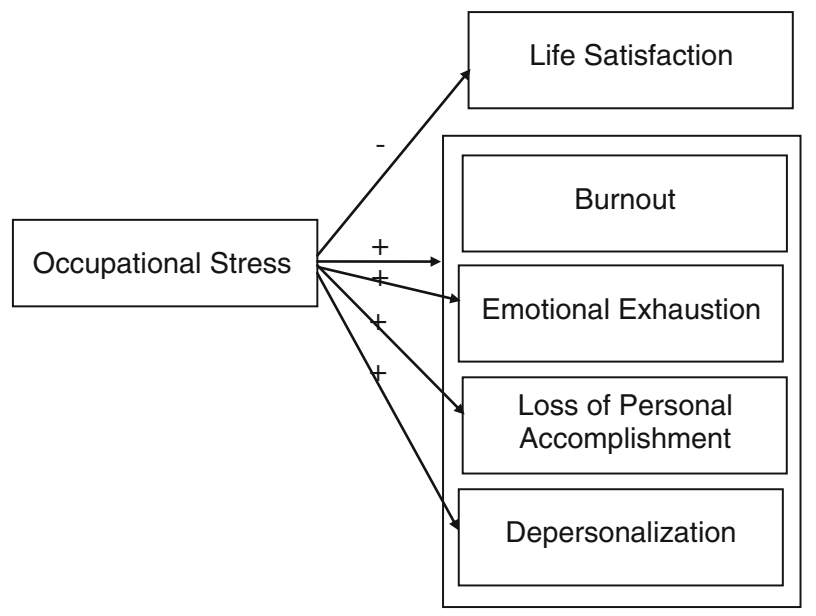

In the course of our study, we will test two basic hypotheses ( $\mathrm{H} 1$ and $\mathrm{H} 2)$ and three sub-hypotheses of the latter (H3, H4 and H5). These hypotheses are:

Hypothesis 1 : Occupational stress has a meaningful and negative effect on life satisfaction.

Hypothesis 2 : Occupational stress has a meaningful and positive effect on general burnout.

Hypothesis 3 : Occupational stress has a meaningful and positive effect on emotional exhaustion.

Hypothesis 4 : Occupational stress has a meaningful and positive effect on lack of personal accomplishment.

Hypothesis 5 : Occupational stress has a meaningful and positive effect on depersonalization.

\subsection{Sampling}

The population of our study included accountants and trainee accountants working in Kayseri. There are presently 942 accountants and 508 trainee accountants in Kayseri. A questionnaire 
form designed using convenience sampling was sent to accountants and trainee accountants via e-mail and 217 of them responded. Only 5\% of these were trainees and $95 \%$ were from qualified accountants.

\subsection{Data collection}

Data about the research was collected via the internet through mailed questionnaire forms. The high rate of response to our e-mails shows the interest of accountants in this subject. The e-mail addresses of our sampling groups were obtained from the internet site of the Chamber of Certified Public Accountants of Kayseri. We asked participants to respond in three days. After this period, we called participants by phone and requested that they return the completed forms. In this way, we achieved a response rate of $66.7 \%$.

\subsection{Scales}

There are four parts in our questionnaire forms. In the first part, there are questions about the demographical characteristics of our responders. In the second part, there are tests and scales to measure burnout, emotional exhaustion and life satisfaction levels of participants. The general features of these scales are as follows:

Occupational Stress Scale: The level of occupational stress was measured with the help of the Weiman Occupational Stress Scale (WOSS) (Weiman 1978). The scale was organized as five-point Likert system an was made up of 15 statements. The reliability of the scale was calculated as 0.789. High levels in the scale indicated high levels of occupational stress.

Burnout: In order to measure the burnout levels of our participants, we utilized the "Maslach Burnout Scale" which was designed by Maslach and Jackson in (1981), and this was adapted to Turkish and tested by Ergin (1992) in terms of validity and reliability. The burnout scale is made up of three sub-scales: emotional exhaustion, lack of personal accomplishment, and depersonalization. There are 22 statements representing the three sub-scales. The scale is five-pointed and asks about the frequency of certain statements. The general reliability of this scale is calculated as 0.70 (Cronbach Alfa). The reliability of emotional exhaustion is 0.69 , lack of personal accomplishment is 0.72 and 0.70 for depersonalization. The level of burnout is calculated with the average of a Likert type scale.

Life Satisfaction: The life satisfaction levels of accountants in the study were determined with the help of the "Satisfaction with Life Scale" designed by Diener et al. (1985). There are 7 points and five statements in this scale. The reliability rate of the scale is 0.75 .

\section{Results}

\subsection{Findings on demographical features}

The demographical features of the participants in our questionnaire are given in terms of gender, work experience, age and education in Table 1:

The demographical features of the sample are ignored in terms of variables in the research model. There was no analysis on the differences or relations and no hypothesis was proposed. We asked demographical questions in order to obtain information about the sampling and the kind of sampling for the sake of future studies. Demographical variables were not directly related to our research. Furthermore, these questions were asked in order to maintain as source of sampling to further studies. 
Table 1 Demographical features of participants in the study

\begin{tabular}{lll}
\hline Gender & $\mathrm{f}$ & $\%$ \\
\hline Male & 160 & 73.7 \\
Female & 57 & 26.3 \\
Work experience & & \\
$0-5$ years & 40 & 18.4 \\
6-10 years & 79 & 36.4 \\
11-15 years & 64 & 29.4 \\
16 years and more & 34 & 18.8 \\
Age & & \\
20-30 year & 64 & 29.5 \\
31-40 year & 71 & 32.7 \\
41-50 year & 57 & 26.2 \\
51 years and above & 25 & 11.6 \\
Education & & \\
High school & 72 & 33.2 \\
College & 67 & 30.8 \\
Undergraduate & 67 & 30.8 \\
Graduate & 11 & 5.2 \\
\hline
\end{tabular}

\subsection{Mean value of variables}

The mean and standard deviation values of our variables are as follows:

\begin{tabular}{lll}
\hline & Mean & SD \\
\hline Occupational stress & 3.07 & 0.62 \\
Life satisfaction & 2.60 & 1.23 \\
Emotional exhaustion & 3.62 & 1.06 \\
Lack of personal accomplishment & 3.51 & 1.19 \\
Depersonalization & 3.04 & 1.06 \\
Burnout (General) & 3.40 & 0.73 \\
\hline
\end{tabular}

In the study we monitored occupational stress levels slightly over the average score (3.07), life satisfaction below the average (2.60) and general level of burnout above the average point (3.40). Regarding the sub-dimensions of burnout, the highest level of burnout is for emotional exhaustion and the lowest level is for depersonalization.

\subsection{Correlation}

According to the results of the study, the correlation between occupational stress, life satisfaction, burnout and sub-elements of burnout (emotional exhaustion, lack of personal accomplishment, depersonalization) is as follows:

According to Table 2 there is a negative correlation between occupational stress and life satisfaction. This correlation shows that as long as the occupational stress levels of professionals increase their life satisfaction level decreases. There is a positive correlation between occupational stress and all types of burnout. This represents the fact that as the occupational levels of accountants raise so too does their burnout levels. From another aspect, when these 
Table 2 Correlation matrix

\begin{tabular}{lllllll}
\hline & 1 & 2 & 3 & 4 & 5 & 6 \\
\hline 1. Occupational stress & 1.00 & & & & & \\
2. Life satisfaction & $-0.404^{* *}$ & 1.00 & & & & \\
3. Emotional exhaustion & $0.384^{* *}$ & $-0.273^{* *}$ & 1.00 & & & \\
4. Lack of personal accomplishment & $0.509 * *$ & $-0.364^{* *}$ & $0.406^{* *}$ & 1.00 & & \\
5. Depersonalization & $0.270^{* *}$ & $-0.321^{* *}$ & $0.135^{*}$ & $0.214^{* *}$ & 1.00 & \\
6. Burnout & $0.550^{* *}$ & $-0.440^{* *}$ & $0.714^{* *}$ & $0.789 * *$ & $0.621^{* *}$ & 1.00
\end{tabular}

$* p<0.05, * * p<0.01$

Table 3 The results of regression analysis about the effects of occupational stress on life satisfaction

\begin{tabular}{lllll}
\hline$R$ & $R^{2}$ & Corrected $R^{2}$ & SE of estimation & $F$ \\
\hline 0.404 & 0.163 & 0.159 & 1.13 & $41.956^{* * *}$ \\
\hline
\end{tabular}

$* * P<0.01$

Dependent variable: life satisfaction. Independent variable: occupational stress

Table 4 Beta factor about the effects of occupational stress on life satisfaction

\begin{tabular}{llll}
\hline Not Standardized $\beta$ & SE & Standardized $\beta$ & $t$ \\
\hline-0.800 & 0.124 & -0.404 & $-6.477 * *$ \\
\hline
\end{tabular}

$* * P<0.01$

Dependent variable: life satisfaction. Independent variable: occupational stress

professionals have greater occupational stress their life satisfaction increases and they feel less burnout.

\subsection{Testing hypotheses}

There are two basic hypotheses in our study. The first one is H1;"Meaningful negative effect of occupational stress on life satisfaction" as mentioned in our model. The hypothesis is:

H 1 Occupational stress has a meaningful negative effect on life satisfaction.

In order to test this hypothesis, regression analysis was performed. The results of the regression analysis on $\mathrm{H} 1$ are given in Table 3 as well as the beta factor of the effect of occupational stress life satisfaction in Table 4.

When we consider the issue in the light of the information given in Tables 3 and 4, occupational stress shows an effect on life satisfaction of $15.9 \%$. The beta factor that explains the effect of stress on life satisfaction is -0.404 . This shows that stress has a meaningful negative effect on life satisfaction. Therefore, as the effect of occupational stress on life satisfaction is meaningful and negative, $\mathrm{H} 1$ is proven.

The second basic hypothesis mentioned in the research model is $\mathrm{H} 2$ "the positive and meaningful effect of occupational stress on burnout":

H 2 Occupational stress has a positive and meaningful effect on burnout.

Hypotheses 3, 4 and 5 are sub-hypotheses of $\mathrm{H} 2$. Their regression analyses were performed separately and are shown by the beta factors in Tables 5 and 6 . That there are more than one 
Table 5 Regression analysis results of effects of occupational stress on burnout and its sub-dimensions

\begin{tabular}{llllll}
\hline & $R$ & $R^{2}$ & Corrected $R^{2}$ & SE of estimation & $F$ \\
\hline Burnout in general & 0.550 & 0.302 & 0.299 & 0.65 & $93.015^{* *}$ \\
Emotional exhaustion & 0.384 & 0.147 & 0.143 & 0.98 & $37.127^{* *}$ \\
Lack of personal accomplishment & 0.509 & 0.259 & 0.255 & 1.03 & $74.642^{* *}$ \\
Depersonalization & 0.270 & 0.073 & 0.069 & 1.02 & $16.841^{* *}$ \\
\hline
\end{tabular}

*** $P<0.01$

Dependent variable: life satisfaction. Independent variable: occupational stress

Table 6 Beta factors of effects of occupational stress on burnout and its sub-dimensions

\begin{tabular}{lllll}
\hline & Not standardized $\beta$ & SE & Standardized $\beta$ & $t$ \\
\hline Burnout & 0.693 & 0.072 & 0.550 & $9.644^{* *}$ \\
Emotional exhaustion & 0.652 & 0.107 & 0.384 & $6.093^{* *}$ \\
Lack of personal accomplishment & 0.977 & 0.113 & 0.509 & $8.640^{* *}$ \\
Depersonalization & 0.461 & 0.112 & 0.270 & $4.104^{* *}$ \\
\hline
\end{tabular}

*** $P<0.01$

Dependent variable: life satisfaction. Independent variable: occupational stress

beta factor in the same table, does not mean a multiple regression analysis. As the dependent variable is occupational stress and independent variables are burnout and its sub-dimensions.

When we evaluate Tables 5 and 6 together, we see that occupational stress has a positive and meaningful effect on burnout and it sub-dimensions it therefore increases the level of burnout. It is understood that the lowest rate of occupational stress is in depersonalization $(\beta$ : $0.270)$ and the highest rate is in lack of personal accomplishment $(\beta: 0.509)$. In accordance with the data in Tables 5 and 6, hypotheses 2, 3, 4 and 5 are proven.

Considering the results of regression analyses, we see the meaningful effects of occupational stress experienced by accountants on levels of life satisfaction and burnout. Therefore, occupational stress can be named as cause of both life satisfaction and burnout.

\section{Discussion and conclusion}

This study was conducted in order to determine whether or not the occupational stress of accountants has meaningful effects on levels of life satisfaction and burnout together with its sub-dimensions. In order to achieve our goal, we designed a research model and we proposed the testing of two basic hypotheses in this model $(\mathrm{H} 1$ and $\mathrm{H} 2)$ and three sub-hypotheses $(\mathrm{H} 3$, $\mathrm{H} 4, \mathrm{H} 5)$.

The first basic hypothesis is that occupational stress will lessen the life satisfaction of accountants. Regarding the data collected, occupational stress does lessen the life satisfaction. The effect of occupational stress on life satisfaction is $(-) 0.404$.

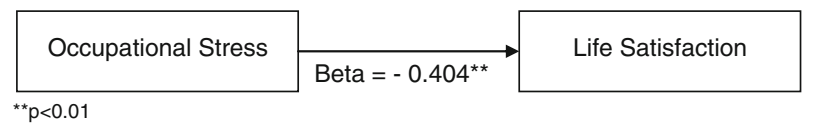


Controlling the stress levels of accountants is vital in terms of life satisfaction. The less life satisfaction accountants have, the more physical and psychological problems they have at work in addition to their own family problems. In this respect, programs that will help to decrease the stress levels of accountants will be of great benefit. Learning different ways of decreasing stress levels and knowing about stress management will have a positive effect on accountants' lives. The effect of occupational stress on life satisfaction is negative and its level is about $40.4 \%$.

The second basic hypothesis is that stress will increase the level of general burnout in accountants. Analyses showed that occupational stress has a positive and meaningful effect on the burnout levels of individuals.

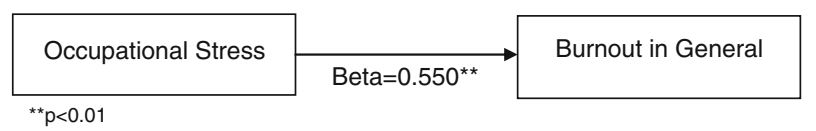

Whether occupational stress is chronic in accountants is hard to estimate through results of our study. However, the effects of stress may be chronic. Occupational stress exhausts individuals in the course of time. Burnout is one of the most important psychological illnesses of this century. From this point of view, precautions should be taken, both individually and organizationally, to decrease the stress level of accountants. It was observed that the effect of occupational stress on burnout is positive, at about $55 \%$.

Together with the second basic hypothesis, the third, fourth and fifth sub-hypotheses concerned the effects of occupational stress on burnout levels. Analyses showed that occupational stress has an effect on all three sub-dimensions.

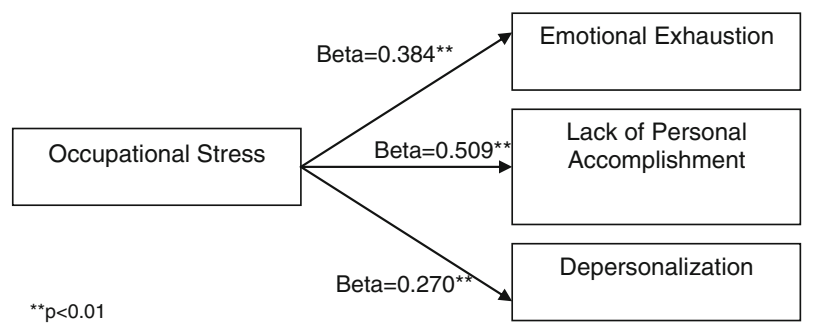

When we consider the figure above, we see that occupational stress has more effect on lack of personal accomplishment than on the other two sub-dimensions (Beta $=50.9 \%$ ). After lack of personal accomplishment, occupational stress is respectively effective on emotional exhaustion and depersonalization. When an individual feels lack of personal accomplishment, he/she feels incapable of doing his/her job. Then, the individual believes that there is a general negativity surrounding him/her and decides that he/she does not have a future in his/her occupation that he/she is going backwards or that his/her efforts do not make sense. Naturally, these feelings are a major problem for accountants working for the public. This is because, in depersonalization, the individual ignores other people, and acts and becomes emotionless by ignoring him/herself.

When individuals feel burnout, they think that they are not as productive as before and do not offer as good a service as they did in the past, this results in feelings of distress and incapacity, which causes anxiety and the desire not to go to work. 
Accountancy, which means defining, evaluating and reporting the recorded economical procedures of an organization in order to assist users to make decisions, is like a bridge between information users and the organization. The information produced by accountants should be reliable, comparable, comprehensible and helpful in the decision process. Otherwise, decisions taken according to this information will not be sound. Therefore, we it is necessary to help accountants, a very important group of professionals in our lives, to rid themselves of stress and burnout. These precautions will result in happy and healthy members of the public, a highly esteemed profession and economical developments as well as social. Accountants are known as "people who only prosecute legal issues and accountancy records". However, they are actually qualified to issue reports about the technical, administrative and economical aspects of any organization. In this respect, accountants must be informed about possible dangers and precautions about burnout syndrome and it should be covered during in-service training and in the pre-occupational period as a part of occupational education. Likewise, there should be practical training during university and at work about the techniques necessary to avoid stress and occupational stress.

This study may be re-conducted in other cities and using different scales. The scales for burnout, occupational stress and life satisfaction may be modified. There are many other scales using these variables in the literature. This study and future studies may be compared and in this way, we may contribute to the literature.

Open Access This article is distributed under the terms of the Creative Commons Attribution License which permits any use, distribution, and reproduction in any medium, provided the original author(s) and the source are credited.

\section{References}

Aktas, A.M., Aktas, R.: İş Stresi, Verimlilik Dergisi. Milli Prodüktivite Yayınları 2(1), 153-170 (1992)

Antoniou, A.G., Davidson, M.J., Cooper, C.L.: Occupational Stress, Job Satisfaction and Health State in Male and Female Junior Hospital Doctors in Greece. J. Manag. Psychol. 18(6), 592-621 (2003)

Ardic, K., Polatsci, S.: Tükenmişlik Sendromu Akademisyenler Üzerinde Bir Uygulama (GOÜ Örneği). Gazi Üniversitesi İIBBF Dergisi 10(2), 69-96 (2008)

Artan, I.: Örgütsel Davranış (In) "Örgütsel Stres Kaynakları ve Yöneticiler Üzerinde Bir Uygulama”, Özgün Matbaacilık, İstanbul (1986)

Ay, M., Avsaroglu, S.: Muhasebe Calısanlarının Mesleki Tükenmişlik, Iş Doyumu ve Yasam Doyumlarının Incelenmesi, Mesleki Tükenmislik Düzeyleri. Uluslararası İnsan Bilimleri Dergisi 7(1), 1170$1189(2010)$

Aydin, S.: Örgütsel Stres Yönetimi. Dokuz Eylül Üniversitesi Sosyal Bilimler Enstitüsü Dergisi 6(3), 4974 (2004)

Baltas, A., Baltas, Z.: Stres ve Başa Çıkma Yolları, Remzi Kitabevi, 10. Baskı, İstanbul (1990)

Bastemur, Y.: İş Tatmini ile Yaşam Tatmini Arasındaki İlişkiler: Kayseri Emniyet Müdürlüğü’nde Bir Araştırma. Erciyes Üniversitesi. Sosyal Bilimler Enstitüsü. Yayınlanmamış Yüksek Lisans Tezi. Kayseri (2006)

Beehr, T.A., Newman, J.E.: Job Stress, Employee Health and Organization Effectiveness' A Facet Analysis, Model and Literature Review. Pers. Psychol. Winter, 665-669 (1978)

Budak, G., Surgevil, O.: Tükenmişlik ve Tükenmişliği Etkileyen Örgütsel Faktörlerin Analizine İlişkin Akademik Personel Üzerinde Bir Uygulama. D.E.Ü.İ̈.B.F. Dergisi 20(2), 95-108 (2005)

Cannon, W.B.: The emergency function of the adrenal medulla in pain and other emotions. Am. J. Physiol. 33, 356-372 (1914)

Cooper, C.L., Marshall, J.: Occupational Sources of Stress: A Review of the Literature Relating to Coronary Heart Disease and Mental Ill Health. J. Occup. Psychol. 49, 11-28 (1976)

Cokluk, O.: Örgütlerde Tükenmişlik: Yönetimde Çağdaş Yaklaşımlar (Ed: Cevat Elma ve Kamile Demir). Anı Yayıncılık. Ankara (2000)

Davis, K., Newstrom, J.W. : Organizatianol Behavior: Human Behavior at Work. Mcgraw-Hill, New York (1988) 
Diener, E., Emmons, R.A., Larsen, R.J., Griffin, S.: The Satisfaction with Life Scale. J. Pers. Assess. 49, 71-75 (1985)

Dikmen, A.A.: İş Doyumu ve Yaşam Doyumu İlişkisi. Ankara Üniversitesi. Siyasal Bilgiler Fakültesi 50(3), 115-140 (1995)

Dockery, A.M..: Happiness, Life Satisfaction and the Role of Work: Evidence From Two Australian Surveys. http://www.melbourneinstitute.com/hilda/biblio/cp/conf-hd05.pdf, Accessed Aug 01, 2008 (2004)

Erdogan, I.: İşletme Yönetiminde Örgütsel Davranış. İşletme İktisadı Enstitüsü, İstanbul (1996)

Eren, E.: Örgütsel Davranış ve Yönetim Psikolojisi. Beta Yayıncılık. Geliştirilmiş, 9. Baskı, İstanbul (2006)

Ergin, C.: Doktor ve Hemşirelerde Tükenmişlik ve Maslach Tükenmişlik Ölçeğinin Uyarlanması. VII. Ulusal Psikoloji Kongresi Bilimsel Çalışmaları. 22-25 Eylül 1992. Hacettepe Üniversitesi. VII. Ulusal Psikoloji Kongresi Düzenleme Kurulu ve Türk Psikologlar Derneği Yayını. Ankara (1992)

Ertas, F.: İşletmelerde Muhasebe Organizasyonu ve Muhasebe Mesleği, 1. Baskı, Seçkin Yayınları (2002)

Fairbrother, K., Warn, J.: Workplace dimensions, stress \& job satisfaction. J. Manager. Psychol. 18(1), 8-21 (2003)

Freudenberger, H.: Staff Burnout. J. Soc. Issues 30, 159-165 (1974)

Gokdeniz, I.: Üretim Sektöründeki İşletmelerin Örgüt İçi Stres Kaynakları ve Mobilyacılık Sektöründe Bir Uygulama. Selçuk Üniversitesi. Sosyal Bilimler Enstitüsü Dergisi 13, 173-189 (2005)

Haratani, T, Kawakami, N.: Work Stress and Health '99: Organization of Work in a Global Economy. www.cdc.gov/niosh/stress99.html Accessed Aug 1, 2008 (1999)

Heller, D., Judge, T.A., Watson, D.: The Confounding Role of Personality and Trait Affectivity in The Relationship Between Job and Life Satisfaction. J. Org. Behav. 23, 815-835 (2002)

Hellriegel, D., Slocum, J.W., Woodman, R.W.: Organizational Behavior. West Publishing, New York (1983)

Ivancewich, J.M., Donnelly, J.H., Gibson, J.L.: Managing for Performance. Business Publications. Inc, Plano (1983)

Kahn, R.L., Byosiere, P.: The Organization Behavior Reader, 6th edn. Prentice Hall Inc, Lebanon (1995)

Kop, N., Euwema, M.C.: Occupational Stress and the Use of Force by Dutch Police Officers. Crim. Just. Behav. 28, 631-652 (2001)

Mackay, C.J., Cousins, R., Kelly, P.J., Lee, S., Mccaig, R.H.: Management standards and work-related stress in the UK: policy background and science. Work Stress 18(2), 91-112 (2004)

Magnuson, J.: Stress management. J. Prop. Manag. (May-June) 55(3) (1990)

Mansor, A.T., Fontaine, R., Chong, S.C.: Occupational Stress Among Managers: a Malaysian Survey. J. Manag. Psychol. 18(6), 622-628 (2003)

Maslach, C., Jackson, S.E.: The Measurement of Experienced Burnout. J. Occup. Behav. 2, 99-113 (1981)

Maslach, C., Zimbardo, P.G.: Burnout: The Cost of Caring. Prentice-Hall. Inc, Englewood Cliffs (1982)

Maslach, C., Leiter, M.P.: The Truth About Burnout. Jossey-Bass, San Francisco (1997)

Maslach, C., Schaufeli, W.B., Leiter, M.P.: Job Burnout. Ann. Rev. Psychol. 52, 397-422 (2001)

Ozdevecioğlu, M.: İş Tatmini ve Yaşam Tatmini Arasındaki İlişkinin Belirlenmesine Yönelik Bir Araştırma. 11.Ulusal Yönetim Ve Organizasyon Kongresi. 22-24 Mayıs. Afyon (2003)

Ozdevecioğlu, M., Aktas, A.: Kariyer Bağımlılığı, Mesleki Bağlılık ve Örgütsel Bağlılığın Yaşam Tatmini Üzerindeki Etkisi: İş-Aile Çatışmasının Rolü. Erciyes Üniversitesi. İktisadi Ve İdari Bilimler Fakültesi Dergisi 28, 1-20 (2007)

Saldamli, A: Örgütsel Davranışta Seçme Konular. In: Özdevecioğlu, M., Karadal, H. Mesleki Stres, İlke Yayınevi, Ankara (2008)

Saris, W.E., Scherpenzeel, A.C., Veenhoven, R., Bunting, B.: In: A Comparative Study of Satisfaction with Life in Europe, pp. 11-48. Erasmus University Press, Budapest (1996)

Schaufeli, W.B., Buunk, B.P.: Burnout: an overview of 25 years of research and theorizing. In: Schabracq, M.J., Winnubst, Jacques, A.M., Cooper, Cary L. (eds.) The Handbook of Work and Health Psychology, pp. 383-425. John Wiley, New York (2003)

Selye, H.: Stress Without Distress. Teach Yourself Books, vol. 3 (21) (1977)

Stacciarini, J.M.R., Troccoli, B.T.: Occupational Stress and Constructive Thinking: Health and Job Satisfaction. J. Adv. Nurs. 46(5), 480-487 (2004)

Surgevil, O.: Çalışma Hayatında Tükenmişlik Sendromu. Nobel Yayın Dağıtım, Yayinci (2006)

Telman, N., Ünsal, P.: Çalışan Memnuniyeti. Epsilon Yayınevi, İstanbul (2004)

Ugoji, E.I., Isele, G.: Stress management \& corporate governance in Nigerian organizations. Eur. J. Sci. Res. 27(3), 472-478 (2009)

Veenhoven, R.: Questions on happiness: Classical topic, modern answer, blind spots. In: Strack, F., Argyle, M., Schwarz, N. (eds.) Subjective well-being: An interdisciplinary approach, pp. 7-26. Pergamon Press, Great Britain (1991)

Weiman, C.: A Study of occupational stressors. J. Occup. Med. 19, 119-122 (1978) 
Wright, T.A., Bonnet, D.G.: The Contribution of Burnout to Work Performance. J. Org. Behav. 18, 491499 (1997)

Yildirim, S.: Muhasebe Öğretim Elemanları ve Meslek Mensuplarının Mesleki Stres Düzeyi Üzerine Bir Araştırma. Muhasebe ve Finansman Dergisi (38): 153-162 (2008)

Yilmaz, A., Ekici, S.: Örgütsel Yaşamda Stresin Kamu Çalışanlarının Performansına Etkileri Üzerinde Bir Araştırma. Yönetim Ve Ekonomi Dergisi 10(2), 1-19 (2003) 